\title{
Analgesic and Anti-Inflammatory Activities of Diethyl Ether and n-Hexane Extract of Polyalthia suberosa Leaves
}

\author{
Nelufar Yasmen, ${ }^{1}$ Md. Abdullah Aziz ${ }^{(D)},{ }^{1}$ Afsana Tajmim, ${ }^{1}$ Mst. Irin Akter, ${ }^{2}$ \\ Amit Kumar Hazra, ${ }^{1}$ and S. M. Mushiur Rahman ${ }^{1}$ \\ ${ }^{1}$ Department of Pharmacy, Jessore University of Science \& Technology, Jessore 7408, Bangladesh \\ ${ }^{2}$ Department of Pharmacy, Stamford University Bangladesh, Dhaka 1217, Bangladesh \\ Correspondence should be addressed to Md. Abdullah Aziz; a.aziz@just.edu.bd
}

Received 30 September 2017; Accepted 25 December 2017; Published 23 January 2018

Academic Editor: Ke Ren

Copyright (C) 2018 Nelufar Yasmen et al. This is an open access article distributed under the Creative Commons Attribution License, which permits unrestricted use, distribution, and reproduction in any medium, provided the original work is properly cited.

In folk medicine, Polyalthia suberosa is used as abortifacient, laxative, febrifuge analgesic, filler of tooth cavities, and anti-HIV drug and for rheumatism and various skin infections. The present study was directed to evaluate the analgesic and anti-inflammatory activities of diethyl ether and n-hexane extracts of Polyalthia suberosa leaves (PSDE and PSNH). A variety of tests including formalin-induced paw licking test, acetic acid induced writhing test, and tail immersion test were used to assess the analgesic activity. In addition, xylene-induced ear edema test was used to evaluate anti-inflammatory activity of PSDE and PSNH. PSDE and PSNH at 200 and $400 \mathrm{mg} / \mathrm{kg}$ doses expressed analgesic as well as anti-inflammatory activities in mice. In formalin-induced paw licking test, acetic acid induced writhing test, and xylene-induced ear edema test, the extracts exhibited significant inhibition $\left({ }^{*} P<0.05\right.$ versus control) of pain and inflammation. Alternatively, in tail immersion test, PSDE $400 \mathrm{mg} / \mathrm{kg}$ showed significant $\left({ }^{*} \mathrm{P}<0.05\right.$ versus control) latency at $30 \mathrm{~min}$ but another tested sample had no significant latency. From this study, it could be shown that Polyalthia suberosa leaves may contain analgesic and anti-inflammatory agents which support its use in traditional medicine.

\section{Introduction}

Since the beginning of human being development, various medicinal plants are used as traditional medicines for remedial purpose. Plants possess the capability of producing biologically interesting and valuable chemical constituents $[1,2]$.

Polyalthia suberosa Roxb. is an evergreen shrub or small tree, which is naturally grown and widely distributed throughout Bangladesh, India, China, Malaysia, Myanmar, Sri Lanka, Philippine, Thailand, and Vietnam [3-5]. However, it is locally recognized as Jam debharu or Hamjam [6, 7]. It has corky barks, narrowly oblong or oblong-lanceolate, long acuminate, shining leaves, rusty tomentose, young branchlets, and so on. [8]. It is traditionally used as abortifacient, laxative, febrifuge analgesic, anti-HIV drug, and filler of tooth cavities $[4,6,9]$. Other documented folk medicinal uses of this plant are rheumatism and various skin infections [10]. In addition, seeds of this plant were considered as sedative, diuretic, and soporific [4]. A review of literature of this plant proposed that Polyalthia suberosa has a variety of activities including analgesic, cytotoxic, antibacterial, neuropharmacological, and antioxidant activity $[3,6,10,11]$.

Pain is an incapacitating accompaniment of many medical conditions [12] and according to the International Association for the Study of Pain (IASP), it is defined as "an unpleasant sensory and emotional experience associated with actual or potential tissue damage" $[13,14]$. It always gives a warning signal and is primarily protective in nature but often causes a lot of discomfort and leads to many adverse effects [15]. Different biochemical mediators like prostaglandins, bradykinins, and substance $\mathrm{P}$ act on the nociceptors causing the sensation released by tissue injury and are considered as the immediate cause of pain. It can be either chronic or 
acute. Quick onset and short duration of pain that last for hours are regarded as acute pain, whereas chronic pain is characterized by persistent pain over a long period of time [16-18]. So, control of pain is one of the most important therapeutic priorities [12].

Inflammation is a permeative phenomenon that operates during severe impatience of homeostasis, such as infection, injury, and exposure to contaminants and this process is triggered by innate immune receptors and recognizes the pathogens to remove them [19]. This is a defense mechanism which is characterized by redness, pain, heat, swelling, and loss of function in the affected area $[20,21]$. In the formation of inflammation, both the innate immune response and the acquired immune response are involved [22-25]. In mammalian cells, at least two isoforms COX-1 and COX-2 subsist, where COX-1 is distributed constitutively in almost all cell types, including platelets and those present in stomach, vascular endothelium, kidney, forebrain, and uterine epithelium regulated as a house keeping enzyme for various physiological functions. On the other hand, during tissue damage or inflammation in response to proinflammatory cytokines such as IL1, interferon gamma, and TNF- $\alpha$, COX-2 is expressed and induced [26-29].

Both NSAIDs (Nonsteroidal Anti-Inflammatory Drugs) and steroidal drugs are used to treat pain and inflammation. However, long-term use of NSAIDs causes various adverse effects and damage liver, gastrointestinal tract, and so on. Besides, they initiate cardiovascular problems and renal failure [30-33]. Steroids may suppress the immune system and trigger erectile dysfunction, manic depression, hypertension, cramps and dizziness, appearance of dormant diabetes, skin atrophy, decreased bone density, stomach ulcers with possible perforation of the stomach wall, irregular menstruation, vision and allergic problems, and reduced wound healing $[34,35]$. Moreover, opioid analgesics are used in pain management which have adverse effects for example, dependence, constipation, and respiratory problems [36].

For resisting these adverse effects, exploration of new analgesic and anti-inflammatory drugs are till now an arduous project and research is crucial to discover various alternatives. Plant based medicines may fulfill this requirement by providing nontoxic, more potent, efficacious, and safe drugs to treat pain and inflammation. Therefore, the aim of this study was to evaluate the analgesic as well as antiinflammatory attributes of Polyalthia suberosa leaves.

\section{Materials and Methods}

2.1. Chemicals and Reagents. Diclofenac sodium was used as standard drug in this study and obtained from Square Pharmaceutical Ltd., Bangladesh; another standard drug, tramadol hydrochloride (TH), was purchased from Beximco Pharmaceutical Ltd., Bangladesh. All solvents used were of analytical grade and obtained from Merck, Germany.

2.2. Collection and Identification of Plant. At first with the help of a comprehensive literature review, Polyalthia suberosa (family Annonaceae) was selected for this investigation.
Leaves of this plant were collected from Phultala, Khulna, Bangladesh, that is located at $22.9750^{\circ} \mathrm{N}, 89.4583^{\circ} \mathrm{E}$. Species identification was verified by Naymur Rahman, Principal Scientific Officer at the Bangladesh National Herbarium, and the accession number is 44988. A dried specimen was deposited in the herbarium for future reference.

2.3. Extraction. After collection, the leaves were rinsed with water and dried in room temperature and then in air oven (LY-660, DONGGUAN LIYI Test Equipment Co. Ltd., China) at reduced temperature (not more than $40^{\circ} \mathrm{C}$ ) to be suitable for grinding purpose. After that, leaves were ground into fine powder using high capacity grinding mill (Model 2000 LAB Eriez, USA) and then stored in air-tight container. Cold extraction procedure was used for preparing the extracts. Diethyl ether and n-hexane extracts were prepared by separately immersing $200 \mathrm{~g}$ powder of Polyalthia suberosa leaves in 2 L diethyl ether and n-hexane (Mark, Germany) for 7 days. Whatman number 1 filter papers were used to filter the liquid extracts. The filtrates were then dried in air to get solid residues. The extraction yields of PSDE and PSNH leaves were $8.34 \%(\mathrm{w} / \mathrm{w})$ and $6.23 \%(\mathrm{w} / \mathrm{w})$, respectively. However, both extracts were stored at $4^{\circ} \mathrm{C}$ for additional studies.

2.4. Experimental Animals. For the experiment, eighty Swiss albino mice of either sex, 6-7 weeks of age, weighing between 25 and $30 \mathrm{~g}$, were purchased from International Center for Diarrhoeal Disease Research Bangladesh, Mohakhali, Dhaka, Bangladesh. Throughout the experiment, animals stayed under standard environmental conditions (temperature: 27.0 $\pm 1.0^{\circ} \mathrm{C}$, relative humidity: $55-65 \%$, and $12 \mathrm{~h}$ light $/ 12 \mathrm{~h}$ dark cycle) with one-week adaptation before experiment. They were housed in cages made of polypropylene and had free access to feed and water ad libitum. All protocols for animal experiment were approved by the Institutional Animal Ethical Committee of Jessore University of Science and Technology, Jessore, Bangladesh.

2.5. Acute Toxicity Study. Acute toxicity results from a single exposure or multiple exposures of an ingredient within a short period (normally less than $24 \mathrm{~h}$ ). This study was carried out according to the guidelines of Organization of Economic Cooperation and Development (OECD) for defining the half lethal dose $\left(\mathrm{LD}_{50}\right)$ of the experimental samples. To conduct this study, fifteen mice were separated into three groups: control group and test groups (PSDE and PSNH), with each group having five animals. At various concentrations $(100,250,500,1000,2000,3000$, and $4000 \mathrm{mg} / \mathrm{kg}$ body weight), the experimental samples were administered orally. At that moment, some parameters were observed such as mortality, diarrhea, noisy breathing, salivation, convulsion, injury, changes in locomotor activity, weakness, discharge from eyes and ears, coma, pain, aggressiveness, food or water rejection, or any other signs of toxicity in each group of animals for 5-6h. And these parameters were monitored at the end of every hour also. Moreover, each group of animals was kept under observation for 2 weeks for the final assessment $[37,38]$. 


\subsection{Evaluation of Analgesic Activity}

2.6.1. Formalin-Induced Paw Licking Test. Formalin-induced paw licking test was performed according to Hunskaar and Hole [39]. Twenty mice were selected for this test and divided into four groups, having five mice in each group, and they were fasted for $16 \mathrm{~h}$ with water ad libitum. Control group, standard group, and test groups were treated with distilled water $(10 \mathrm{~mL} / \mathrm{kg})$, diclofenac sodium (DS, $100 \mathrm{mg} / \mathrm{kg})$, PSDE, and PSNH at 200 and $400 \mathrm{mg} / \mathrm{kg}$, respectively. All of the treatment processes were done by oral gavage. Moreover, $1 \mathrm{~h}$ later of treatment, each mouse was injected with $20 \mu \mathrm{L}$ of $2.7 \%(\mathrm{v} / \mathrm{v})$ formalin solution into the dorsal surface of left hind paw. Animals were observed for 5 min after injection, which was considered as acute phase. Again, they were monitored for $5 \mathrm{~min}$ after $20 \mathrm{~min}$ of injection which was defined as late phase. The percentage of inhibition of licking was calculated by the following formula.

$$
\begin{aligned}
& \text { Inhibition (\%) } \\
& =\left[1-\left(\frac{\text { Licking time (standard or extracts) }}{\text { Licking time (normal control) }}\right)\right] \\
& \times 100
\end{aligned}
$$

2.6.2. Acetic Acid Induced Writhing Test. This test was performed according to Koster et al. [40]. Mice were kept unfed for $16 \mathrm{~h}$ with water ad libitum prior to the experiment and pretreated with extracts as mentioned before. DS $(100 \mathrm{mg} / \mathrm{kg})$ acted as standard or positive control, whereas distilled water acted as normal control. Each mouse was injected intraperitoneally with $0.7 \%(\mathrm{v} / \mathrm{v})$ acetic acid at a dose of $10 \mathrm{~mL} / \mathrm{kg}$ body weight after $45 \mathrm{~min}$ of respective treatment. The number of writhing responses was recorded for each animal during a 5 min period, which began after 15 min of acetic acid administration. To calculate the percentage of inhibition of writhing, the following formula was used.

$$
\begin{aligned}
& \text { Inhibition (\%) } \\
& =\left[1-\left(\frac{\text { No. of writhing }(\text { standard or extracts) }}{\text { No. of writhing (normal control) }}\right)\right] \\
& \times 100
\end{aligned}
$$

2.6.3. Tail Immersion Test. This test was conducted according to Toma et al. [41]. Central mechanism of pain or analgesic activity can be evaluated by this experiment. Thermal stimuli act as the generator of painful reaction through dipping the tail tip in hot water $\left(55 \pm 1^{\circ} \mathrm{C}\right)$. Mice were grouped and treated as described before. Here, tramadol hydrochloride $(10 \mathrm{mg} / \mathrm{kg})$ was used as reference drug. Basal reaction time was counted for each mouse after one hour of treatment. The counting was after $30,60,90$, and $120 \mathrm{~min}$ of the respective treatment to determine the latency period. Moreover, each group was also monitored for latency period before $30 \mathrm{~min}$ of treatment. The animal which had more than $15 \mathrm{~s}$ latency periods was removed from the experiment and $15 \mathrm{~s}$ acts as cut-off point to avoid injury.

\subsection{Evaluation of Anti-Inflammatory Activity}

2.7.1. Xylene-Induced Ear Edema. The method of Dai et al. [42] was used to evaluate xylene induced ear edema in mice. Twenty mice were divided into four groups: negative control group (distilled water, $10 \mathrm{~mL} / \mathrm{kg}$ body weight), standard group (diclofenac sodium, DS, $100 \mathrm{mg} / \mathrm{kg}$ body weight), and test groups (200 and $400 \mathrm{mg} / \mathrm{kg}$ body weight), having five mice in each group. Negative control $(10 \mathrm{~mL} / \mathrm{kg})$ received one dose of distilled water, where the standard group $(100 \mathrm{mg} / \mathrm{kg})$ treated with diclofenac sodium (DS) as well as test groups received PSDE and PSNH at 200 and $400 \mathrm{mg} / \mathrm{kg}$ orally. Each animal received $20 \mu \mathrm{L}$ of xylene on the anterior and posterior surfaces of the right ear lobe one hour after the particular treatment. The left ear was kept untreated and considered as control. After one hour of xylene application, the mice were sacrificed and $6 \mathrm{~mm}$ circular sections of the ears were taken by using a cork borer and weighed. The difference between weight of ear treated with xylene (right ear) and the weight of ear left untreated (left ear) was considered as the weight of xylene-induced edema. The percentage inhibition of ear edema was calculated by the following formula.

$$
\begin{aligned}
& \text { Inhibition (\%) } \\
& =\left[1-\left(\frac{\text { Weight of edema (standard or extracts) }}{\text { Weight of edema (control) }}\right)\right] \\
& \quad \times 100
\end{aligned}
$$

2.8. Statistical Analysis. All results are expressed as mean \pm standard error of mean (SEM). All data were analyzed statistically by one-way ANOVA followed by Dunnett's $t$ test. Pairwise comparison of means among the groups was analyzed by one-way ANOVA followed by post hoc Tukey's HSD test.

In addition, the results of tail immersion test were analyzed by using repeated measure ANOVA (RM-ANOVA). $P<0.05$ was considered to be statistically significant. SPSS software (version 17; IBM Corporation, New York, USA) was used to analyze all the data.

\section{Results}

From the acute toxicity study, sign of toxicity or mortality was not observed up to the high dose of $4000 \mathrm{mg} / \mathrm{kg}$ for PSDE as well as PSNH or control group. There was no change in food intake or other behaviors during 2-week observation period and was the same as prior to the experiment. This seemingly specified that the test groups did not express acute oral toxicity.

The effects of formalin-induced paw licking test of diethyl ether and n-hexane extracts of Polyalthia suberosa in mice are shown in Table 1. Tested samples (orally administered, $200 \mathrm{mg} / \mathrm{kg}$ and $400 \mathrm{mg} / \mathrm{kg}$ ) suppressed the licking, persuaded by formalin in the biphasic pain response, those divided as the neurogenic pain response or the early phase, and the inflammatory pain response or the late phase. All the tested samples produced significant inhibition $\left({ }^{*} P<0.05\right.$ versus 
TABLE 1: Effect of PSDE and PSNH in formalin-induced paw licking test.

\begin{tabular}{|c|c|c|c|c|c|}
\hline \multirow{2}{*}{ Group } & \multirow{2}{*}{ Dose } & \multicolumn{2}{|c|}{ Acute phase } & \multicolumn{2}{|c|}{ Late phase } \\
\hline & & Licking time (s) & Inhibition (\%) & Licking time (s) & Inhibition (\%) \\
\hline Control & $10 \mathrm{~mL} / \mathrm{kg}$ & $84.40 \pm 4.64$ & $0.00 \pm 0.00$ & $59.00 \pm 3.91$ & $0.00 \pm 0.00$ \\
\hline DS & $100 \mathrm{mg} / \mathrm{kg}$ & $58.00 \pm 7.18^{*}$ & $31.49 \pm 9.71^{*}$ & $12.20 \pm 5.28^{*}$ & $81.14 \pm 7.44^{*}$ \\
\hline PSDE & $200 \mathrm{mg} / \mathrm{kg}$ & $71.00 \pm 6.05$ & $16.89 \pm 7.51$ & $31.00 \pm 7.45^{*}$ & $47.70 \pm 10.60^{*}$ \\
\hline PSDE & $400 \mathrm{mg} / \mathrm{kg}$ & $63.20 \pm 3.20$ & $26.10 \pm 3.67$ & $23.60 \pm 8.39^{*}$ & $62.75 \pm 11.97^{*}$ \\
\hline PSNH & $200 \mathrm{mg} / \mathrm{kg}$ & $64.20 \pm 9.65$ & $25.04 \pm 11.01$ & $32.40 \pm 8.23^{*}$ & $44.95 \pm 12.95^{*}$ \\
\hline PSNH & $400 \mathrm{mg} / \mathrm{kg}$ & $59.80 \pm 4.44^{*}$ & $30.31 \pm 4.53^{*}$ & $25.40 \pm 6.45^{*}$ & $52.59 \pm 9.24^{*}$ \\
\hline
\end{tabular}

All of the experimental values are denoted as mean \pm SEM. ${ }^{*} P<0.05$ versus control (Dunnett's $t$-test).

TABLE 2: Effect of PSDE and PSNH in acetic acid induced writhing test.

\begin{tabular}{lccc}
\hline Group & Dose & Writhing number & Inhibition (\%) \\
\hline Control & $10 \mathrm{~mL} / \mathrm{kg}$ & $22.00 \pm 2.62$ & $0.00 \pm 0.00$ \\
DS & $100 \mathrm{mg} / \mathrm{kg}$ & $2.60 \pm 0.74^{* \$}$ & $88.68 \pm 3.61^{* \$}$ \\
PSDE & $200 \mathrm{mg} / \mathrm{kg}$ & $12.80 \pm 3.30^{*}$ & $44.08 \pm 15.78^{*}$ \\
PSDE & $400 \mathrm{mg} / \mathrm{kg}$ & $10.20 \pm 3.29^{*}$ & $57.86 \pm 12.37^{*}$ \\
PSNH & $200 \mathrm{mg} / \mathrm{kg}$ & $9.20 \pm 1.01^{*}$ & $59.86 \pm 6.23^{*}$ \\
PSNH & $400 \mathrm{mg} / \mathrm{kg}$ & $5.80 \pm 2.03^{*}$ & $75.53 \pm 8.36^{*}$ \\
\hline
\end{tabular}

All of the experimental values are denoted as mean \pm SEM. ${ }^{*} P<0.05$ versus control (Dunnett's $t$-test). ${ }^{\$} P<0.05$ versus PSDE $200 \mathrm{mg} / \mathrm{kg}$ (pairwise comparison by post hoc Tukey's HSD test).

TABLE 3: Analgesic effect of PSDE and PSNH in tail immersion test.

\begin{tabular}{lcccccc}
\hline \multirow{2}{*}{ Group } & Dose & \multicolumn{3}{c}{ Latency period (s) } \\
& & $0 \mathrm{~min}$ & $+30 \mathrm{~min}$ & $+60 \mathrm{~min}$ & $+90 \mathrm{~min}$ & $+120 \mathrm{~min}$ \\
\hline Control & $10 \mathrm{~mL} / \mathrm{kg}$ & $1.4680 \pm 0.14$ & $1.42 \pm 0.29$ & $1.41 \pm 0.16$ & $1.74 \pm 0.16$ & $1.20 \pm 0.30$ \\
TH & $10 \mathrm{mg} / \mathrm{kg}$ & $1.7020 \pm 0.14$ & $6.96 \pm 1.50^{*}$ & $6.68 \pm 2.00^{*}$ & $4.48 \pm 2.19$ & $4.07 \pm 1.21^{*}$ \\
PSDE & $200 \mathrm{mg} / \mathrm{kg}$ & $1.5180 \pm 0.14$ & $2.87 \pm 0.33$ & $3.74 \pm 1.31$ & $2.61 \pm 0.62$ & $2.06 \pm 0.27$ \\
PSDE & $400 \mathrm{mg} / \mathrm{kg}$ & $1.6540 \pm 0.21$ & $4.47 \pm 0.67^{*}$ & $3.75 \pm 1.89$ & $2.17 \pm 0.25$ & $2.64 \pm 0.38$ \\
PSNH & $200 \mathrm{mg} / \mathrm{kg}$ & $1.6540 \pm 0.25$ & $2.71 \pm 0.52$ & $2.01 \pm 0.50$ & $1.83 \pm 0.14$ & $1.77 \pm 0.28$ \\
PSNH & $400 \mathrm{mg} / \mathrm{kg}$ & $1.2920 \pm 0.10$ & $3.12 \pm 0.63$ & $2.56 \pm 0.30$ & $2.41 \pm 0.13$ & $2.07 \pm 0.11$ \\
\hline
\end{tabular}

Latency period evaluated from this study is represented as mean \pm SEM. 0 min indicates 30 min before treatment and $+30,+60,+90$, and +120 mean after $30 \mathrm{~min}, 60 \mathrm{~min}, 90 \mathrm{~min}$, and $120 \mathrm{~min}$ of treatment, respectively. Tests of within-subjects effects reveal that for the factor "time" calculated $F=9.30$ for all methods and $P$ value $=0.000$ in every case. So, time is highly significant at any level of significance. ${ }^{*} P<0.05$, versus control. Repeated measure analysis of variance with Dunnett's multiple comparison was performed to analyze this data set.

control) in late phase, whereas in acute phase only PSNH $400 \mathrm{mg} / \mathrm{kg}$ showed significant inhibition $(30.31 \pm 4.53 \%)$.

The result of acetic acid induced writhing test was summarized in Table 2. Diclofenac sodium (DS) $100 \mathrm{mg} / \mathrm{kg}$ was used as positive control and the inhibition of the acetic acid induced writhing was observed as $88.68 \pm 3.61 \%$. Orally administered tested samples expressed notable differences in the writhing occurrence and they antagonized the pain sensation. Tested samples showed significant $\left({ }^{*} P<0.05\right.$ versus control) inhibition of writhing and the highest percentage of inhibition was shown by PSNH $400 \mathrm{mg} / \mathrm{kg}(75.53 \pm 8.36 \%)$.

The results of analgesic activity of Polyalthia suberosa diethyl ether and n-hexane extracts measured by tail immersion test were given in Table 3. At $30 \mathrm{~min}$, PSDE $400 \mathrm{mg} / \mathrm{kg}$ showed significant $\left({ }^{*} P<0.05\right.$ versus control) latency but other tested samples had no significant latency. Tramadol hydrochloride $(10 \mathrm{mg} / \mathrm{kg})$ was found to be effective and significant $\left({ }^{*} P<0.05\right.$ versus control) at 30,60 , and $120 \mathrm{~min}$.
The result of anti-inflammatory activity obtained from xylene-induced ear edema in mice is shown in Table 4. All of the groups showed significant $\left({ }^{*} P<0.05\right.$ versus control) inhibition of ear edema and differences of ear weight. Among the extracts, $65.92 \% \pm 1.62 \%$ is the highest value of inhibition that was provided by PSNH $400 \mathrm{mg} / \mathrm{kg}$.

\section{Discussion}

Till now very limited toxicity studies have been carried out on plant derived products. However, not only adverse effects of any plant material but also its safe doses can be determined by acute oral toxicity test [37].

In this study, $\mathrm{LD}_{50}$ of the plant extracts could not be obtained, as no mortality was observed up to the dose as high as $4000 \mathrm{mg} / \mathrm{kg}$ and the extracts were found to be safe with a broad therapeutic range. Therefore, two comparatively high 
TABLE 4: Effect of PSDE and PSNH in xylene-induced ear edema in mice.

\begin{tabular}{lccc}
\hline Group & Dose & Ear weight difference $(\mathrm{mg})$ & Inhibition $(\%)$ \\
\hline Control & $10 \mathrm{~mL} / \mathrm{kg}$ & $32.60 \pm 2.65$ & $0.00 \pm 0.00$ \\
DS & $100 \mathrm{mg} / \mathrm{kg}$ & $10.00 \pm 0.54^{* \$}$ & $68.33 \pm 3.61^{* \$}$ \\
PSDE & $200 \mathrm{mg} / \mathrm{kg}$ & $18.20 \pm 1.24^{*}$ & $42.70 \pm 5.57^{*}$ \\
PSDE & $400 \mathrm{mg} / \mathrm{kg}$ & $12.20 \pm 2.26^{*}$ & $62.67 \pm 4.65^{*}$ \\
PSNH & $200 \mathrm{mg} / \mathrm{kg}$ & $15.80 \pm 2.69^{*}$ & $48.54 \pm 12.00^{*}$ \\
PSNH & $400 \mathrm{mg} / \mathrm{kg}$ & $11.00 \pm 0.70^{* \$}$ & $65.92 \pm 1.62^{* \$}$ \\
\hline
\end{tabular}

Ear weight differences are denoted as mean \pm SEM. ${ }^{*} P<0.05$ versus control(Dunnett's $t$-test). ${ }^{\$} P<0.05$ versus PSDE $200 \mathrm{mg} / \mathrm{kg}$ (pairwise comparison by post hoc Tukey's HSD test).

doses $(200$ and $400 \mathrm{mg} / \mathrm{kg}$ ) for both PSDE and PSNH were used for in vivo doses.

The formalin-induced paw licking test is a trustworthy method for investigating nociception as well as possible mechanism of analgesia. Two distinct mechanisms are associated with the biphasic behavior of pain in this test [39]. The early phase is considered as neurogenic pain phase which is induced by direct stimulation through formalin that starts instantly after the formalin solution has been injected and lasts for 5-10 min. The late phase shows inflammatory pain which arises from the spinal neuro-hyperactivity involving various mediators which are started by the C-fibers. Peripherally acting drugs act only on the late phase but centrally acting drugs show good response in both phases [16, 43, 44]. The results of the formalin test stated that PSDE and PSNH work on late phase and inhibit inflammatory mediators, whereas in acute phase PSNH $400 \mathrm{mg} / \mathrm{kg}$ showed significant inhibition. Maximum inhibition was exhibited by PSDE $400 \mathrm{mg} / \mathrm{kg}$ $(62.75 \pm 11.97 \%)$.

Globally acetic acid induced writhing test is being primarily used for the assessment of antinociceptive activity of natural composites $[45,46]$. The release of different endogenous noxious mediators such as bradykinin, serotonin, histamine, and substance $\mathrm{P}$ is induced by acetic acid. Contraction of abdominal muscle goes together with expansion of the forelimbs and body elongation that characterize the pain which is brought about by acetic acid [2, 46, 47]. Local peritoneal receptors as well as prostaglandin pathways are thought to be responsible for abdominal contraction [48-51]. In this study, PSDE and PSNH showed significant inhibition of acetic acid induced writhing and this may occur due to the inhibition of endogenous mediators or blockage of prostaglandin pathways.

The tail immersion test is an important acute pain model [52] and it assesses the centrally acting analgesic and opioid receptor agonist. Opioids analgesic activities are ascertained through spinal $(\delta 2, \sigma 2$, and $\kappa 1)$ and supraspinal $(\delta 1, \sigma 1$, and $\kappa 3)$ receptors [53]. The opioid $\mu$ receptor demonstrates more sensitivity to thermal induced nociceptive test like tail immersion test. Opioids can start their antinociceptive activity in both acute and late phases of pain model [37, 54]. Table 3 shows that plant extracts showed less effect on inhibition of tail withdrawal and there was no significant latency period, except PSDE $400 \mathrm{mg} / \mathrm{kg}$ at $30 \mathrm{~min}(P<0.05)$.
So, there is less possibility of the involvement of opioids. Now it is necessity for broad studies to reveal the exact pain inhibitory mechanism of actions of the plant extracts.

Inflammation has four cellular processes, which are changes in blood flow by changing in smooth muscle cell function that are accountable for vasodilatation, alteration of the vascular permeability, migration phagocytic leukocytes to the site of inflammation, and phagocytosis [55]. Xyleneinduced ear edema test is done as acute inflammatory test. In addition, xylene can release inflammatory mediators such as bradykinin, histamine, and serotonin. These mediators are responsible for edema as they enhance vascular permeability and improve vasodilation [56]. Fluid accumulation occurs at the treatment site, which is shown by the xylene-induced ear edema test and inhibition of this fluid accumulation is considered as anti-inflammatory effect [57]. Topical steroids or nonsteroidal anti-inflammatory agents inhibit phospholipase A2 which can be evaluated by the xylene-induced ear edema test [37]. Here, PSDE and PSNH produced significant inhibition of ear edema that may be due to the blockage of phospholipase A2, reduction of vascular permeability, and vasodilation. But extensive study is required to assure the exact mechanism, through which the extracts suppressed edema.

\section{Conclusion}

From the present study, it could be proposed that the diethyl ether and n-hexane extracts of Polyalthia suberosa leaves might possess analgesic and anti-inflammatory activities. Now it is under investigation of isolating and determining the active constituents and structures of Polyalthia suberosa leaves. However, further quantifiable studies are now essential to categorize the particular mechanism which is responsible for the analgesic and anti-inflammatory activities of Polyalthia suberosa leaves. At last but not least, to be a safe therapeutic agent, not only acute oral toxicological evaluation but also genotoxicity study of this plant should be conducted.

\section{Conflicts of Interest}

The authors declare that there are no conflicts of interest regarding the publication of this paper. 


\section{Acknowledgments}

The authors are grateful to the Department of Pharmacy, Jessore University of Science \& Technology, Jessore, Bangladesh, for providing facilities to carry out the research work.

\section{References}

[1] G. Uddin, A. Rauf, B. S. Siddiqui, and S. Q. Shah, "Preliminary comparative phytochemical screening of Diospyros lotus Stewart," Middle-East Journal of Scientific Research, vol. 10, no. 1, pp. 78-81, 2011, https://www.researchgate.net/publication/ 216463074_Preliminary_Comparative_Phytochemical_Screening_of_Diospyros_lotus_Stewart.

[2] A. Rauf, G. Uddin, B. S. Siddiqui, N. Muhammad, and H. Khan, "Antipyretic and antinociceptive activity of Diospyros lotus L. in animals," Asian Pacific Journal of Tropical Biomedicine, vol. 4, supplement 1, pp. S382-S386, 2014.

[3] S. F. Bellah, F. Ahmed, and A. A. Rahman, "Preliminary phytochemical, anti-bacterial, analgesic, anti-diarrhoeal and cytotoxic activity of methanolic extract of Polyalthia suberosa leaves," International Journal of Pharmaceutical Sciences and Research, vol. 3, no. 5, pp. 1322-1326, 2012, https://www.scribd .com/document/95409829/14-Vol-3-Issue-5-May-2012-IJPSR1187-Paper-14.

[4] A. Ghani, Medicinal plants of Bangladesh, The Asiatic Society of Bangladesh, Dhaka, Bangladesh, 2nd edition, 1998, https:// www.scribd.com/document/95409829/14-Vol-3-Issue-5-May2012-IJPSR-1187-Paper-14.

[5] I. M. Turner, "A catalogue of the vascular plants of Malaya, Gardens' Bulletin, Singapore," 1995, http://www.jbpr.in/index.php/ jbpr/article/viewFile/132/137.

[6] R. Mazumdar, M. H. Rahman, M. M. Rahman et al., "Phytochemical and pharmacological investigation of Polyalthia suberosa Roxb," International Journal of Innovative Pharmaceutical Sciences and Research, vol. 4, no. 7, pp. 693-708, 2016, https:// www.researchgate.net/publication/306014972_PHYTOCHEMICAL_AND_PHARMACOLOGICAL_INVESTIGATIONS_OF_ POLYALTHIA_SUBEROSA_ROXB.

[7] G. U. Stuart, "Duhat-matsing, Philippine medicinal plants," 2017, http://www.stuartxchange.org/Duhat-matsing.htm.

[8] E. S. S. Kumar, S. G. Krishnan, K. Murugesan, and S. Shailajakumari, "Notes on Polyalthia malabarica (Bedd.) I.M. Turner and Polyalthia suberosa (Roxb.) Thwaites (Annonaceae)," International Journal of Botany Studies, vol. 1, no. 4, pp. 27-28, 2016, http://www.botanyjournals.com/download/41/1-4-15.

[9] C. P. Khare, Indian Medicinal Plants. An Illustrated Dictionary, Springer, 2007, http://www.springer.com/in/book/ 9780387706375.

[10] S. J. Uddin, R. Rouf, J. A. Shilpi, M. Alamgir, L. Nahar, and S. D. Sarker, "Screening of some Bangladeshi medicinal plants for in vitro antibacterial activity," Oriental Pharmacy and Experimental Medicine, vol. 8, no. 3, pp. 316-321, 2008.

[11] Z. K. Labu, M. Makshud, S. Basir et al., "Study of phytochemical screening, antioxidant, antidiarrhoeal and analgesic activities of hydromethanol extracts of Polyalthia suberosa (Roxb.)," Journal of Biomedical and Pharmaceutical Research, vol. 2, no. 3, pp. 5263, 2013, http://www.jbpr.in/index.php/jbpr/article/viewFile/ $132 / 137$.

[12] M. I. Ezeja, Y. S. Omeh, I. I. Ezeigbo, and A. Ekechukwu, "Evaluation of the analgesic activity of the methanolic stem bark extract of Dialium guineense (Wild)," Annals of Medical and Health Sciences Research, vol. 1, no. 1, pp. 55-62, 2011, https://www.ncbi.nlm.nih.gov/pmc/articles/PMC3507093/.

[13] S. Fan, N. A. Ali, and D. F. Basri, "Evaluation of analgesic activity of the methanol extract from the galls of Quercus infectoria (Olivier) in rats," Evidence-Based Complementary and Alternative Medicine, vol. 2014, Article ID 976764, 6 pages, 2014.

[14] H. Merskey, "Pain terms: a list with definitions and notes on usage. Recommended by the lASP Subcommittee on Taxonomy," PAIN, vol. 6, pp. 249-252, 1979.

[15] S. M. Raquibul Hasan, M.-M. Hossain, R. Akter et al., "Analgesic activity of the different fractions of the aerial parts of Commelina benghalensis Linn," International Journal of Pharmacology, vol. 6, no. 1, pp. 63-67, 2010.

[16] S. Banerjee, A. Mukherjee, and T. K. Chatterjee, "Evaluation of analgesic activities of methanolic extract of medicinal plant Juniperus communis Linn," International Journal of Pharmacy and Pharmaceutical Sciences, vol. 4, supplement 5, 2012, http://www.ijppsjournal.com/Vol4Suppl5/6123.pdf.

[17] H. Merskey and N. Bogduk, Classification of Chronic Pain: Descriptions of Chronic Pain Syndromes and Definitions of Pain Terms, IASP Press, Seattle, Washington, Wash, USA, 2nd edition, 1994, https://www.iasppain.org/files/Content/ContentFolders/Publications2/FreeBooks/Classification-of-ChronicPain.pdf.

[18] M. J. Millan, "The induction of pain: an integrative review," Progress in Neurobiology, vol. 57, no. 1, pp. 1-164, 1999.

[19] M. S. de Melo, J. D. S. S. Quintans, A. A. D. S. Araújo et al., "A systematic review for anti-inflammatory property of clusiaceae family: a preclinical approach," Evidence-Based Complementary and Alternative Medicine, vol. 2014, Article ID 960258, 10 pages, 2014.

[20] T. G. Joseph and S. Reynolds, Principles of Anatomy and Physiology, Harper Collins College Publishers, New York, NY, USA, 7th edition, 1993, https://www.abebooks.com/PrinciplesAnatomy-Physiology-seventh-edition-Tortora/1403034399/bd.

[21] G. Leelaprakash and S. M. Dass, "Invitro anti-inflammatory activity of methanol extract of enicostemma axillare," International Journal of Drug Development and Research, vol. 3, no. 3, pp. 189-196, 2011, http://www.ijddr.in/drug-development/ invitro-antiinflammatory-activity-of-methanol-extractof-enicostemma-axillare.pdf.

[22] A. Azab, A. Nassar, and A. N. Azab, "Anti-inflammatory activity of natural products," Molecules, vol. 21, no. 10, article A119, 2016.

[23] D. Artis and H. Spits, "The biology of innate lymphoid cells," Nature, vol. 517, no. 7534, pp. 293-301, 2015.

[24] K. L. Rock, J.-J. Lai, and H. Kono, "Innate and adaptive immune responses to cell death," Immunological Reviews, vol. 243, no. 1, pp. 191-205, 2011.

[25] A. Waisman, R. S. Liblau, and B. Becher, "Innate and adaptive immune responses in the CNS," The Lancet Neurology, vol. 14, no. 9, pp. 945-955, 2015.

[26] R. U. Shaikh, M. M. Pund, and R. N. Gacche, "Evaluation of anti-inflammatory activity of selected medicinal plants used in Indian traditional medication system in vitro as well as in vivo," Journal of Traditional and Complementary Medicine, vol. 6, no. 4, pp. 355-361, 2016.

[27] D. L. Scott, F. Wolfe, and T. W. J. Huizinga, "Rheumatoid arthritis," The Lancet, vol. 376, no. 9746, pp. 1094-1108, 2010.

[28] E. Lubberts, "Th17 cytokines and arthritis," Seminars in Immunopathology, vol. 32, no. 1, pp. 43-53, 2010. 
[29] R. Sabat, "IL-10 family of cytokines," Cytokine \& Growth Factor Reviews, vol. 21, pp. 315-324, 2010, http://www.cgfr.co.uk/ article/S1359-6101(10)00079-1/fulltext.

[30] D. Murugesan and R. Deviponnuswamy, "Potential antiinflammatory medicinal plants-a review," International Journal of Pharmacy and Pharmaceutical Sciences, vol. 6, no. 4, 2014, http://www.ijppsjournal.com/Vol6Issue4/9208.pdf.

[31] C. Huerta, J. Castellsague, C. Varas-Lorenzo, and L. A. García Rodríguez, "Nonsteroidal anti-inflammatory drugs and risk of ARF in the general population," American Journal of Kidney Diseases, vol. 45, no. 3, pp. 531-539, 2005.

[32] J. L. Wallace, "Pathogenesis of NSAID induced gastro duodenal mucosal injury," Best Practice Research: Clinical Gastroenterology, vol. 15, pp. 691-703, 2001, https://www.ncbi.nlm.nih.gov/ pubmed/11566035.

[33] S.-C. Shih and C.-W. Chang, "Nonsteroidal anti-inflammatory drug-related gastrointestinal bleeding in the elderly," International Journal of Gerontology, vol. 1, no. 1, pp. 40-45, 2007.

[34] Joshua, "Difference between NSAIDs and Steroids," DifferenceBetween.net," 2017, http://www.differencebetween.net/science/ health/drugs-health/difference-between-nsaids-and-steroids/.

[35] A. Moritz, "The dangerous side effects of steroids, arthritis drugs, and NSAIDs,' Ener-Chi Wellness Center," 2011, http://www .ener-chi.com/the-dangerous-side-effects-of-steroids-arthritisdrugs-and-nsaids/.

[36] M. Brennan, "Adverse effects of NSAIDs on renal function," Canadian Medical Association Journal, vol. 131, no. 9, pp. 1012-1013, 1984, https://www.ncbi.nlm.nih.gov/pmc/articles/ PMC1483785/.

[37] M. A. Aziz, "Qualitative phytochemical screening and evaluation of anti-inflammatory, analgesic and antipyretic activities of Microcos paniculata barks and fruits," Journal of Integrative Medicine, vol. 13, no. 3, pp. 173-184, 2015.

[38] M. A. Aziz, K. K. Sarkar, and D. N. Roy, "Acute toxicity study and evaluation of anti-inflammatory \& CNS depressant activities of Richardia scabra," Pharmacologyonline, vol. 3, pp. 70-75, 2015.

[39] S. Hunskaar and K. Hole, "The formalin test in mice: dissociation between inflammatory and non-inflammatory pain," PAIN, vol. 30, no. 1, pp. 103-114, 1987.

[40] R. Koster, M. Anderson, and E. J. De-Beer, "Acetic acid analgesic screening," Federation Proceedings, vol. 18, pp. 412-417, 1959, http://www.scirp.org/(S(351jmbntvnsjtlaadkposzje))/reference/ ReferencesPapers.aspx?ReferenceID=840348.

[41] W. Toma, J. S. Gracioso, C. A. Hiruma-Lima, F. D. P. Andrade, W. Vilegas, and A. R. M. Souza Brito, "Evaluation of the analgesic and antiedematogenic activities of Quassia amara bark extract," Journal of Ethnopharmacology, vol. 85, no. 1, pp. 19-23, 2003.

[42] Y. Dai, L. H. Liu, and J. P. Kou, "Anti-inflammatory effect of aqueous extract of Wu-HU-Tang," China Pharmaceutical University, vol. 6, pp.362-364, 1995, https://www.ncbi.nlm.nih.gov/ pubmed/2600603.

[43] X. Li, P. Sahbaie, M. Zheng et al., "Expression genetics identifies spinal mechanisms supporting formalin late phase behaviors," Molecular Pain, vol. 6, no. 11, 2010, https://link.springer.com/ article/10.1186/1744-8069-6-11.

[44] A. Azadmehr, M. Sofiabadi, and R. Hajiaghaee, "Analgesic effect and immunomodulation response on pro-inflammatory cytokines production by Scrophularia megalantha extract," Tropical Journal of Pharmaceutical Research, vol. 12, no. 6, pp. 935-939, 2014, https://www.researchgate.net/publication/
272442811_Analgesic_Effect_and_Immunomodulation_Response_ on_ProInflammatory_Cytokines_Production_by_Scrophularia_ megalantha_Extract.

[45] H. Khan, M. Saeed, A.-U. Gilani, M. A. Khan, A. Dar, and I. Khan, "The antinociceptive activity of Polygonatum verticillatum rhizomes in pain models," Journal of Ethnopharmacology, vol. 127, no. 2, pp. 521-527, 2010.

[46] M. Ibrar, N. Muhammad, B. ullah et al., "Antinociceptive and anticonvulsant activities of essential oils of Zanthoxylum armatum," Phytopharmacology, vol. 3, no. 1, pp. 191-198, 2012, https://www.researchgate.net/publication/288265374_Antinociceptive_and_anticonvulsant_activities_of_essential_oils_of_Zanthoxylum_armatum.

[47] M. A. Mazid, B. K. Datta, L. Nahar et al., "Analgesic and diuretic properties of $\alpha$-santalone from Polygonum flaccidum," Phytotherapy Research, vol. 24, no. 7, pp. 1084-1087, 2010.

[48] R. K. Sutradhar, A. K. M. M. Rahman, M. Ahmad et al., "Bioactive alkaloid from Sida cordifolia Linn. with analgesic and antiinflammatory activities," Iranian Journal of Pharmacology \& Therapeutics, vol. 5, no. 2, pp. 175-178, 2006, http://www.bioline .org.br/pdf.

[49] A. M. Mat Jais, Y. M. Dambisya, and T.-L. Lee, "Antinociceptive activity of Channa striatus (haruan) extracts in mice," Journal of Ethnopharmacology, vol. 57, no. 2, pp. 125-130, 1997.

[50] A. H. Atta and A. Alkofahi, "Anti-nociceptive and antiinflammatory effects of some Jordanian medicinal plant extracts," Journal of Ethnopharmacology, vol. 60, no. 2, pp. 117124, 1998.

[51] A. Al-Harrasi, L. Ali, J. Hussain et al., "Analgesic effects of crude extracts and fractions of Omani frankincense obtained from traditional medicinal plant Boswellia sacra on animal models," Asian Pacific Journal of Tropical Medicine, vol. 7, no. 1, pp. S485S490, 2014.

[52] M. Z. Imam and C. D. Sumi, "Evaluation of antinociceptive activity of hydromethanol extract of Cyperus rotundus in mice," BMC Complementary and Alternative Medicine, vol. 14, article 83, 2014.

[53] A. S. Muzammil, T. Farhana, and A. Salman, "Analgesic activity of leaves extracts of Samanea saman Merr. and Prosopis cineraria Druce," International Journal of Green Pharmacy, vol. 4, no. 1, pp. 93-95, 2010, https://www.academia.edu/2554155/ Analgesic_activity_ofleaves_extracts_of_Samanea_saman_Merr._ and_Prosopis_cineraria_Druce.

[54] A. E. Oluwatoyin, A. A. Adewale, and A. T. Isaac, "Antinociceptive and anti-inflammatory effects of a Nigerian polyherbal tonic tea (pht) extract in rodents," African Journal of Traditional, Complementary and Alternative Medicines, vol. 5, no. 3, pp. 257-262, 2008, https://www.ncbi.nlm.nih.gov/pubmed/ 20161945.

[55] J. M. Barbosa-Filho, M. R. Piuvezam, and M. D. Moura, "Antiinflammatory activity of alkaloids: a twenty-century review," Revista Brasileria de Farmacognosia, vol. 16, no. 1, pp. 109-139, 2006, http://www.scielo.br/scielo.php?script=sci_arttext\&amp; pid=S0102-695X2006000100020.

[56] S. D. Sokeng, J. Koubé, F. Dongmo et al., "Acute and chronic anti-inflammatory effects of the aqueous extract of Acacia nilotica (L.) Del. (Fabaceae) pods," Academia Journal of Medicinal Plants, vol.1, no. 1, pp.1-5, 2013, https://www.researchgate.net/publication/259979076_Acute_and_chronic_anti-inflammatory_effects_of_the_aqueous_extract_of_Acacia_nilotica_L_ Del_Fabaceae_pods. 
[57] A. Sowemimo, M. Onakoya, M. S. Fageyinbo, and T. Fadoju, "Studies on the anti-inflammatory and anti-nociceptive properties of Blepharis maderaspatensis leaves," Revista Brasileria de Farmacognosia, vol. 23, no. 5, pp. 830-835, 2013, http:// www.scielo.br/scielo.php?script=sci_arttext\&amp;pid=S0102695X2013000500830. 


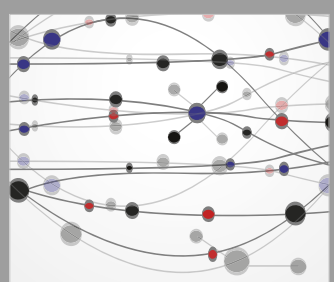

The Scientific World Journal
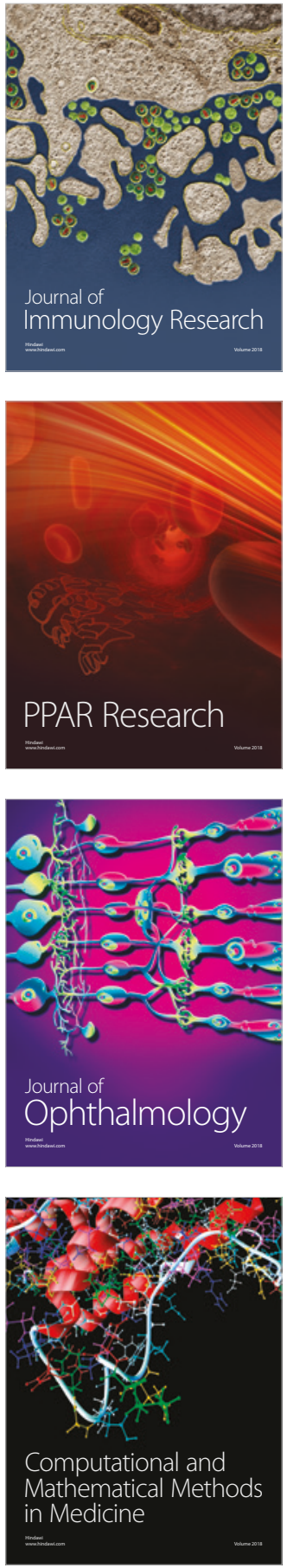

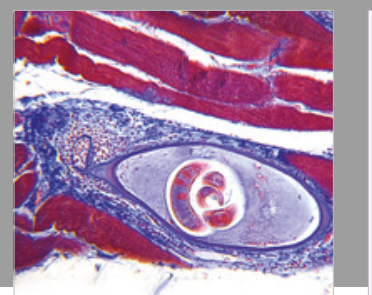

Gastroenterology Research and Practice

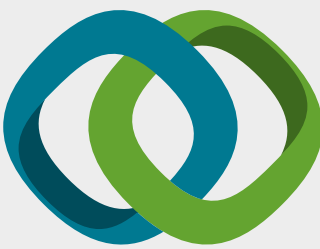

\section{Hindawi}

Submit your manuscripts at

www.hindawi.com
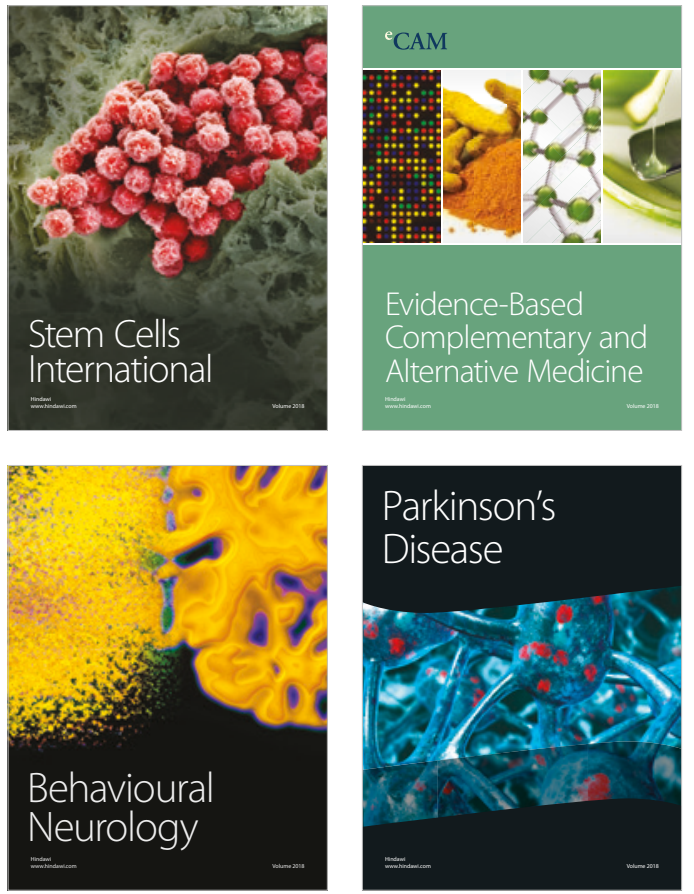

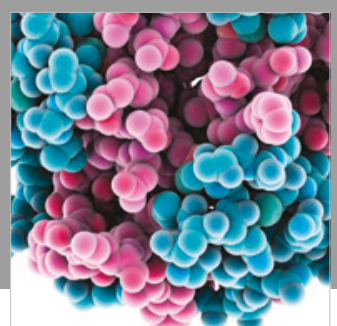

ournal of

Diabetes Research

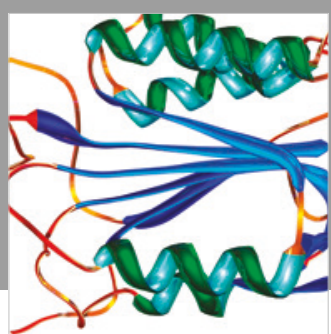

Disease Markers
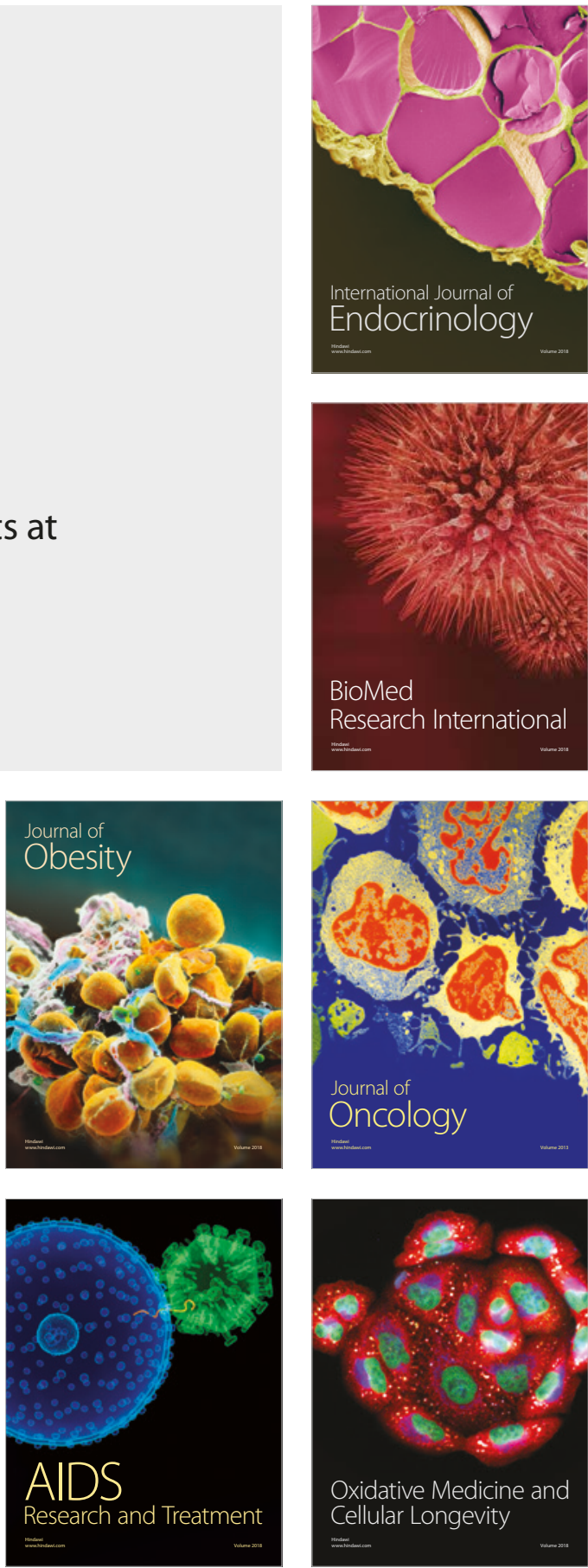